\title{
Evaluating the Impact of Community Based Participatory Watershed Management on crop productivity in the Case of Mount Damota, Wolaita Zone, Southern Ethiopia
}

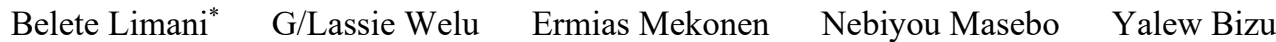 \\ Wolaita Sodo University, P.O. Box: 128, Wolaita, Ethiopia
}

\begin{abstract}
The main objective of study was to evaluate the impact of community based watershed management on crop productivity in the case Mount Damota Watershed in Wolaita Zone, Southern Ethiopia. To address the research questions, the target research site was selected purposely due to the implementation of watershed based SWC practices. To evaluate the impact of the implemented SWC specifically on crop, comparison study and recall method were made to assess the perception of randomly selected respondents. Both primary and secondary sources of data from field observation, focus group discussion, interview and household questionnaire survey as well secondary document review were collected respectively. The collected data were analyzed using SPSS soft version 20. The results show that the field watershed management works are implemented by involving majorities of the local people by organizing in different development teams. Regarding crop productivity of their farm land before the intervention of watershed management the majority $(98 \%)$ of the respondents opinion reflected that as it was decreasing. However, the situation of their farm land crop productivity is reversed to increment after watershed management intervention as the 97\% respondents' opinion. Moreover, the majority (91\%) of respondents have rated the crop productivity as bad (poor) without the project while $71 \%$ as good with the project. Results on the estimation of respondents on some selected commonly produced crops productivity indicated that the productive of the crops increased on average by two folds. Hence, the research concluded that involving local people is important for cost effective implementation of soil and water conservation field work and watershed based activities are playing essential and tangible roles in increasing crop productivity. However, time period for improvements and proportion of land occupied by the installed structures are the main challenges facing the respondents. Therefore, awareness creation training and disseminating improved farm technologies to the respondents should be given priority. Furthermore, empirical studies to be conducted so as to dig out the biophysical and socio-economic impacts of watershed management at different scales.
\end{abstract}

Keywords: Watershed Management, Impact, Crop Productivity, Damota Watershed

DOI: $10.7176 / \mathrm{JRDM} / 69-02$

Publication date:October $31^{\text {st }} 2020$

\section{INTRODUCTION}

\section{Background of the study}

Watershed management is cropping and accepted as a promising approach for conserving water, land, biodiversity and enhancing livelihoods of upland and downstream inhabitants. The practical concept has been contested since 1980s when the conventional techno-centric approach of the time failed to look into the integrative nature of biophysical and socio-economic aspects of the target sites (Tripathi et al., 2007; Yang, 2010; Kumbhar et al., 2012). Above all, the past approaches to natural resource management were fragmented and not responsive to the livelihood of local people rather than blaming them for deterioration of environment (Seaba, 2006; Cornwall, 2008). To end such exclusionary approaches which were sustaining destruction of natural resources and eroding the livelihood of the local people, watershed management has been recommended as forerunner of achieving community based sustainable rural development at the 1992 Earth Summit of the United Nations Conference on Environment and Development (UNCSD, 2012).

Following the recommendation, watershed management has been practiced with objectives of improving livelihood and reducing poverty in developing countries while for conservation natural resources in developed countries (WB, 2008). Thus, in recent decades, greater attention has been given to the watershed inhabitants and their environment which led to inception of integrated watershed management (Sheng, 2001). For instance, pilot integrated watershed managements which were funded by World Bank have played roles in improving biophysical and socio-economic aspects of the local people in many developing countries (Sreedevi et al., 2009).

Watershed management in Ethiopia was started in the 1980s with the aim of natural resource conservation mainly to tackle water-caused soil erosion impacts (Alemneh, 2003;Kebede, 2015). The intervention was merely focused on soil and water conservation for its first two decades of inception (Tesfaye, 2011). However, gradually, it focused on the wise use of natural resources such as land, water and vegetation in given watershed to obtain an optimum level of production with the minimum ecological degradation and active involvement of the community (Lakew et al., 2005). 
Currently, the Ethiopian agricultural transformation agency has launched community based participatory watershed management as main working instrument to use existing natural resources and untapped potentials in both degraded and the remaining potential areas (EPA, 2012). Thus, following the government policy, community based participatory watershed management has been begun by concerned NGOs to address the problem of pervasive food insecurity and degraded livelihood in rural communities of the country in comprehensive manner (CRS, 2010).

Community based participatory watershed approaches have shifted the conventional top-down infrastructure solution in different parts of Ethiopia and there is now a supportive policy and legal framework that facilitates decentralized and participatory development (Evans et al. , 2012). In Wolaita zone, around Mount Damota, where alarming rate of natural resources degradation, loss biodiversity, scarcity of fodder, increasing flood, soil erosion, decrease in soil fertility, land slide and drying out spring are sustaining, community based participatory watershed management activities have been implemented by the government with involvement of the local people. The community based participatory watershed management site is under the supervision of Damota mountain development program which covers 13 kebeles of three bordering woredas of the zone from which 6kebeles are well-treated in collaboration with concerned bodies and active participation of the local people since 2010 (WZARDD, 2009).

\section{Statement of the problem}

Ethiopia is one of the well-endowed countries in sub-saharan African in terms of natural resources and valuable diversity in the production environment. However, land degradation is a treat which has been caused and accelerated by high human and livestock pressures, highly variable and unreliable rainfall, and steep topography. To combat such continuous degradation, watershed management has been implemented for decades by the government of Ethiopia in collaboration with donors in various parts of the country (Tesfaye, 2010; Temesgen, 2015). Currently, the government is committed and implementing watershed management activities to restore the degraded natural resources by mobilizing the local people at different administrative levels of Ethiopia (EPA,2012). According to Kebede (2015), effect of such campaign based watershed management on biophysical and socioeconomic components, challenges and opportunities for replicating and sustaining the activities are rarely evaluated.

Similar to other parts of Ethiopia, community based participatory watershed management is being practiced in different Woredas of Wolaita zone including Mount Damota to overcome natural resource degradations. The depletions are associated with commonly shared resources by the entire community such as water, grazing land and natural forests. This situation has created competition among the community by maximizing the benefits without considering their impacts. The area is also characterized by topography of undulating land with depressions and hills. Hence, it is highly exposed to soil erosion and land degradation. Moreover, natural resources degradation are further aggravated by frequent drought, poverty, absence of clear land tenure, agricultural land fragmentation, institutional deficiencies coupled with increasing population (Pound and Jonfa, 2005).

To counter such alarming situations, community based participatory watershed management has been implemented around Mount Damota. Even though decision makers and experts assume that community based participatory watershed management is the right techniques to improve the biophysical and socio-economic situations, it lacks convincing proof of research based outcome. Thus, evidences for its effectiveness reliant on assertions of the rightness of the approach. Therefore, this study was aimed to evaluate the impacts of community based participatory watershed management on crop productivity in the case of Mount Damota Development area.

\section{Materials and Method Study area description}

The study was conducted around Mount Damota which is geographically located between $6.4^{0}$ and $6.9^{\circ} \mathrm{N}$ latitude, and $37.4^{\circ}$ and $37.8^{\circ} \mathrm{E}$ longitude. Mount Damota is found in Wolaita Zone of the Southern Nations, Nationalities and People's Region (SNNPR). It is about 390km away from Addis Ababa the capital city of Ethiopia and about $5-15 \mathrm{~km}$ from the zonal town Sodo which is bordered by Damote Gale, Sodo Zuria and Boloso Sore Woredas of the zone (WARDD, 2009). 


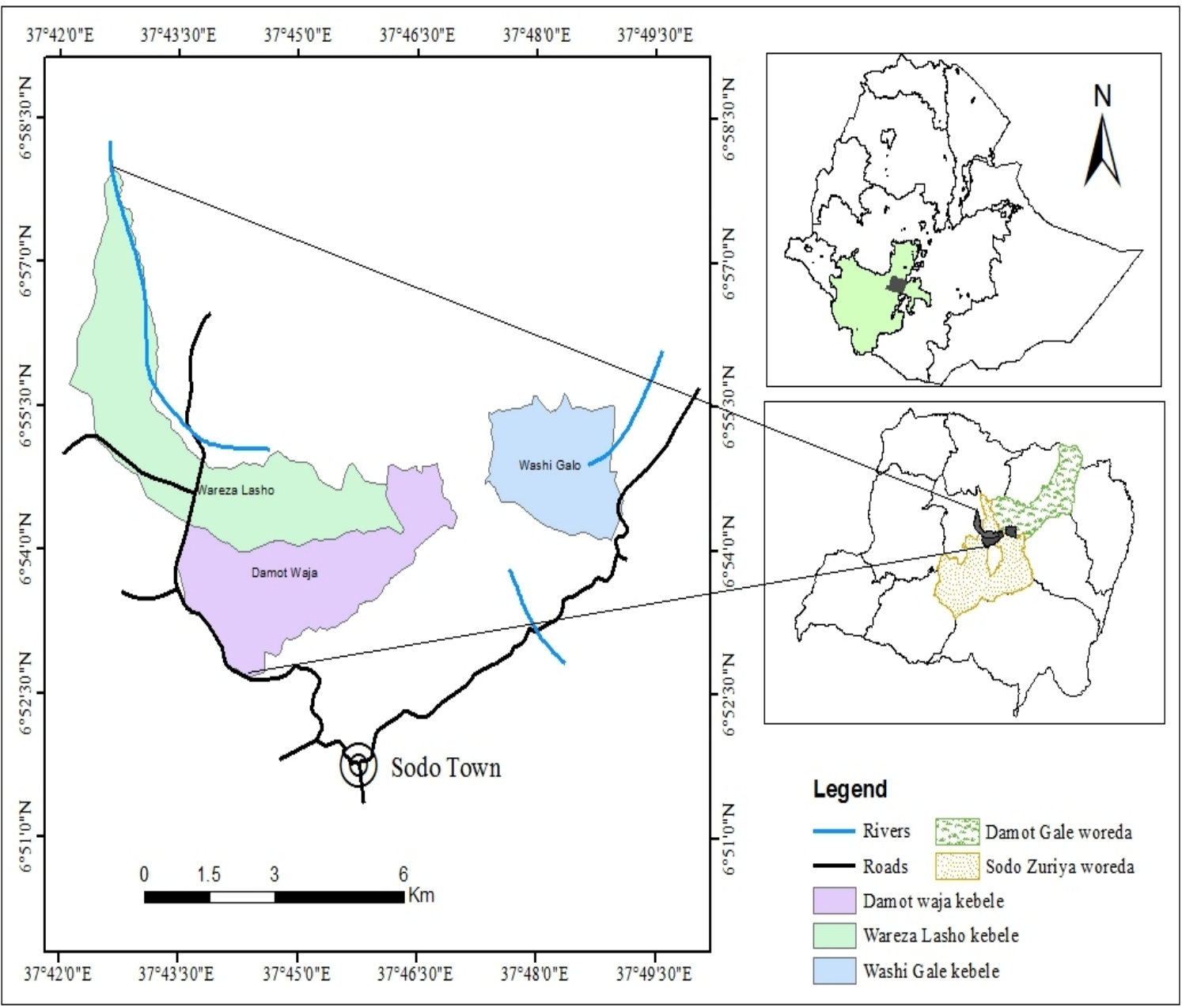

Figure 1: Administrative map of the study site

Agriculture in the study area is mainly subsistent rain-fed crop cultivation practice, with little use of modern agricultural inputs and supplemented with some livestock production. Crop cultivation is carried out on land ranging from gentle to very steep slopes. Although different types of crops are cultivated, the most predominant one are Maize, Barely, Wheat, Bean \& Pea, Root crops and Enset. This constitutes the basis of the economy of the Damota area.

The mean annual temperature of the Damota area varies from $16^{\circ} \mathrm{c}$ to $19.9^{\circ} \mathrm{c}$. The absolute maximum temperature occurs in mid-march and is about $28^{\circ} \mathrm{c}$ and the absolute minimum temperature occurs in November and is about $10.8^{\circ} \mathrm{c}$. The annual mean rainfall from the records in the nearby stations is around $1375 \mathrm{~mm}$.

\section{Methods of data collection}

The study was mainly a kind of survey research. Both qualitative and quantitative data collection methods were used to obtain representative and reliable data from primary and secondary sources. According to the information gained from zonal Agriculture office, already about 28 watersheds with the total area of 5,861.7ha is delineated by using GPS 60. Out of 13 kebeles of the Mount Damota Development program site, Damot Waja and Woshi gale were found as well treated watershed. Therefore, for the study Damot waja and Woshi gale watersheds were selected purposively. During the selection of the sample site, emphasis were given to the implementation of different SWC structures and the accessible of the micro-watersheds .

\section{Sample households selection}

Based on the population data obtained from the base line report of 2009, the total population of the kebeles (Demo waja and Washi gale) is estimated to be 8,368 and 5,52 with 1,395 and 1,607 households. However, within the kebeles, the well treated watershed was inhabited with 840 and 640 households respectively. Therefore, $10 \%$ of the total households (148) were selected for questionnaire survey proportionally.

For this study, data collection methods were determined by the variables of the study to be addressed. In this regard, as the study was focusing on the impact of watershed management on crop productivity of the selected 
watershed of Mount Damota, the data were collected using the following techniques:

Field observation: Before, beginning the actual work, permission was requested from the local administrations to carry out the research. The field observation was focused on biophysical characteristics of watershed like land degradation, crop patterns, distribution of settlements, individual activities in the farming plots, farmers' land management practices and other relevant aspects in the catchment.

Household questionnaire survey: The survey was conducted by using both open and closed ended structured questions. It focused on individual households' productivity improvements due to intervention of watershed management and used recall methods on the basis of household respondents' own recall.

Focused group discussion: Focused group discussion was conducted based on checklists and semi-structured questionnaires prepared for this purpose. The minimum and maximum numbers of people in one group were six and eight respectively. During the discussion focus was given to the status of watershed before the project and the major improvement observed soil condition and crop productivity after project.

Key informant interview: It was carried out with elders, local administrators, experts, and development agents. Identification of key informants who have deep knowledge about the area is essential. They have deep-rooted experience and knowledge of their environment, which was vital to know the details of watershed management in the area. They also played significant role in leading local institutions as they are highly respected in the community. Thus, gaining their consent was an important step. Contacts with development agents and agricultural experts were also of vital to assess the extent of watershed management interventions.

\section{Comparing crop productivity of the site before and after (recall)}

- Crop productivity: The roles of the watershed management activities on crop productivity of the intervention site were assessed by analyzing crop productivity differences before-after watershed management. In the processes households were asked to compare their farm plot crop productiveness with and without the project. The questionnaire based recall method was substantiated by the key informants and focus group discussants recalled data.

- Secondary sources: Both unpublished and published materials such as reports and research journals were reviewed. The document review helped the characterization of status of the target watershed particularly before the project.

\section{Data analysis and interpretation}

The collected data were systematically arranged and presented to simplify the analysis procedure. Moreover, descriptive statistics mainly frequency of information were used to analyze qualitative data through application of SPSS software version 20. Thematic analysis from documented case narratives were employed to interpret and give sense to the relevant qualitative information from the bulk of related themes.

\section{RESULTS AND DISCUSSION}

The results and discussion of the study which was conducted to assess the impact of watershed management specifically focusing on crop productivity are presented as follow.

\section{Community Campaign to Soil and Water Conservation}

Various community groups are involved during watershed management activities. In public campaign work, people participated by contributing labor, farm tools, etc. The campaign team is responsible for watershed development activities and administrating the internal regulations that enforce, encourage and punish in the case of deviation from the norm and agreement of the local people. As the development agent narrated the campaign team is composed of local elders, women associations, youth, religious leaders, kebele officials and traditional healers as listed in table 1 which is taken from the basic information of the surveyed kebeles.

Furthermore, in each surveyed kebele, small 'development teams' or the so-called one to five peer working group have been organized. The number of members in a given team depends on the local situation. The largest development team with 40 members was observed in watershed management intervention site. In all watershed activities, the highest proportion of work has been achieved by the adult male group, for instance, in Waja and Washi gale watershed $85 \%$ of the work was accomplished by the adult male group. The work norm on average is in line to the recommended standard. In this regard, the average soil bund construction was about 6 meters/day for male groups and 3meters/day for women groups. 
Table1: List of different development team in Damot Waja kebele

\begin{tabular}{lllll}
\hline \multirow{2}{*}{ No. } & Development team & Sex & Total \\
\cline { 3 - 4 } & & Male & Female & 2062 \\
\hline 1 & Farmers & 1070 & 992 & 819 \\
2 & Youth & 522 & 297 & 393 \\
3 & Women team & & 393 & 64 \\
4 & Religious leaders & 64 & & 85 \\
5 & Local elders & 78 & 7 & 2 \\
6 & Health experts & 1 & 1 & 30 \\
7 & Craft men & 30 & 2 & 10 \\
8 & Traditional healers & 8 & 2 & 4 \\
9 & Development agents & 2 & & 3,469 \\
\hline \multicolumn{2}{l}{ Total participants in watershed development } & & \\
\hline
\end{tabular}

Source: Damot Waja Kebele watershed development participant summary report (2016)

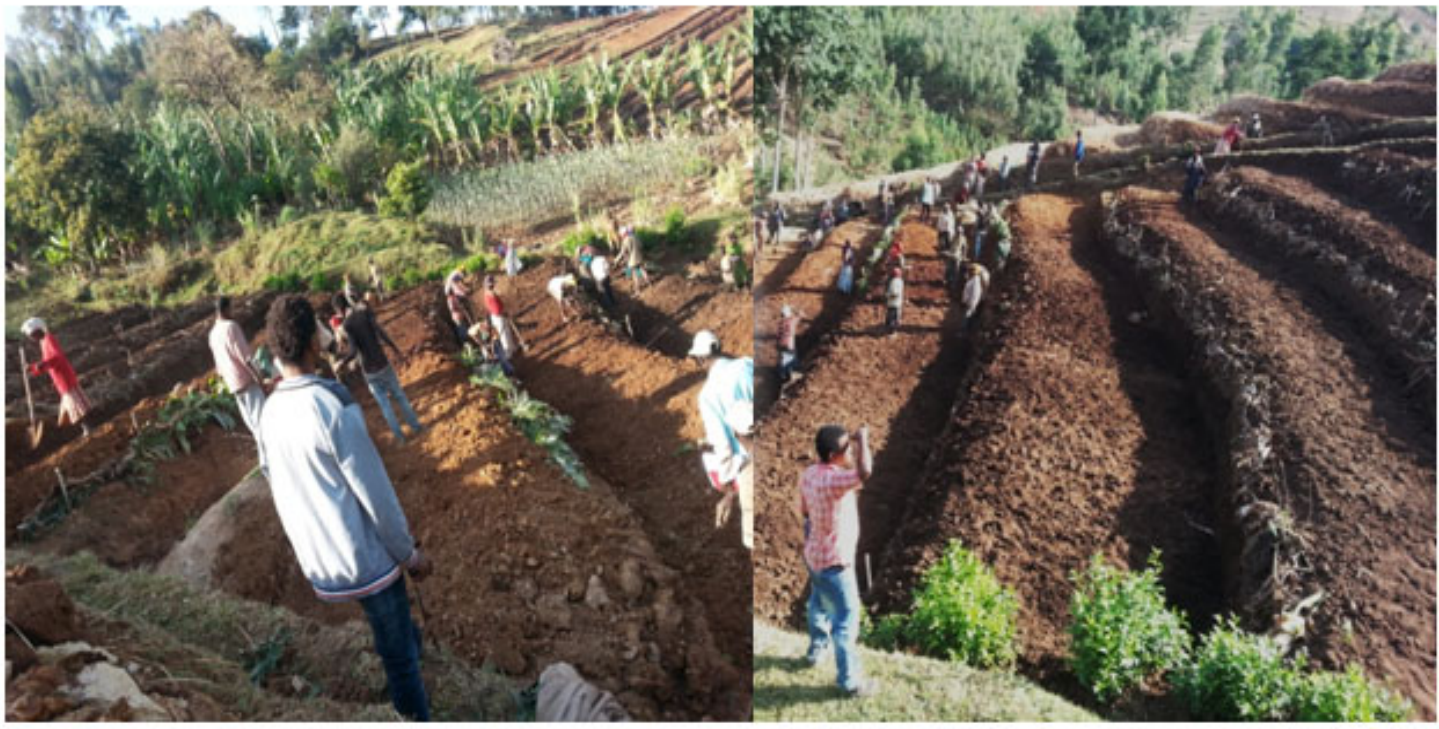

Figure2: Public campaign constructing soil and water conservation structures in Damot Waja Source: field observation photo (2016)

The Impact of the Watershed Management on Crop Productivity

The impact of watershed management on crop productivity was assessed from the view point of the perception of the surveyed household by using recall approach or comparison before and after the project method. In the results and discussion emphasis is given mainly to perception, rating and estimation of the respondents on the impact of watershed management on their farm land crop productivity.

\section{Perception of the respondents on crop productivity}

Perception of interviewed farmers on crop productivity after watershed management was assessed by requesting them to respond their opinion whether their crop yield is increasing, decreasing or no change. Accordingly, majority of the respondents (97.29\%) indicated that there is improvement in their crop yield with the watershed management (Table2).

The discussion further made with respondents revealed that the their crop productivity mainly related with the soil fertility and moisture status improvement as results of continuously implemented watershed based physical and biological soil and waters conservation measures. However, the period required to observe the crop yield improvement and the proportion of land occupied by the different structures and its implication on their productivity are the main challenges indicated by the respondents. In similar studies made by Esser et al. (2002); Alemayehu (2007) and Kebede et al. (2013) showed that watershed based soil and water conservation measures increased soil productive consequently crop yields in the Southern and Northern parts of Ethiopia. 
Table2: crop productivity before and after the project

\begin{tabular}{cll|ll}
\hline Crop productivity & \multicolumn{2}{l}{ Before the project } & \multicolumn{2}{l}{ After the project } \\
\cline { 2 - 5 } & Frequency & Percent & Frequency & Percent \\
\hline Increased & - & - & 144 & 97.29 \\
Decreased & 146 & 98.65 & - & - \\
No change & - & - & 3 & 2.03 \\
Don't know & 2 & 1.35 & 1 & 0.68 \\
\hline Total & 148 & 100.0 & 148 & 100.0 \\
\hline Source: House hold survey (2016) & &
\end{tabular}

Source: House hold survey (2016)

\section{Rating on crop productivity}

Watershed management expert and questionnaire survey participants were asked to rate the status of crop yield from their farm plot before the inception and after the implementation of watershed management. According to the expert, generally the crop yield from the farm households was very low even it was unable to supply their home consumption which in turn was leading them to be dependent on external aid. However, since the intervention of watershed management, the crop yield is found being increased even by three- to- four folds before it was. In addition to the opinion of the field expert, the questionnaire survey participants have made rating on the crop yield of their farm plot before and after the intervention. Therefore, majority of the respondents $(91 \%)$ rated that the crop yield was poor without the watershed management project. But, this situation has changed after the intervention and the yield is rated as good by majorities of respondents (71\%) as shown in figure 3 below respectively.

Recent studies conducted in different parts of Ethiopia showed more less similar results as that of the rating of the respondents on the impact of watershed management on crop productivity. In this regard, Meshesha et al. (2015) study indicated that majority of the respondents rated the productivity of their farm land from average to good after the watershed management intervention in Chena Woreda of Kefa Zone. The same author further analyzed that the rating of the respondents to their farm productivity as good is mainly related with the improvement in the soil fertility and moisture status of their farm land after watershed management intervention.

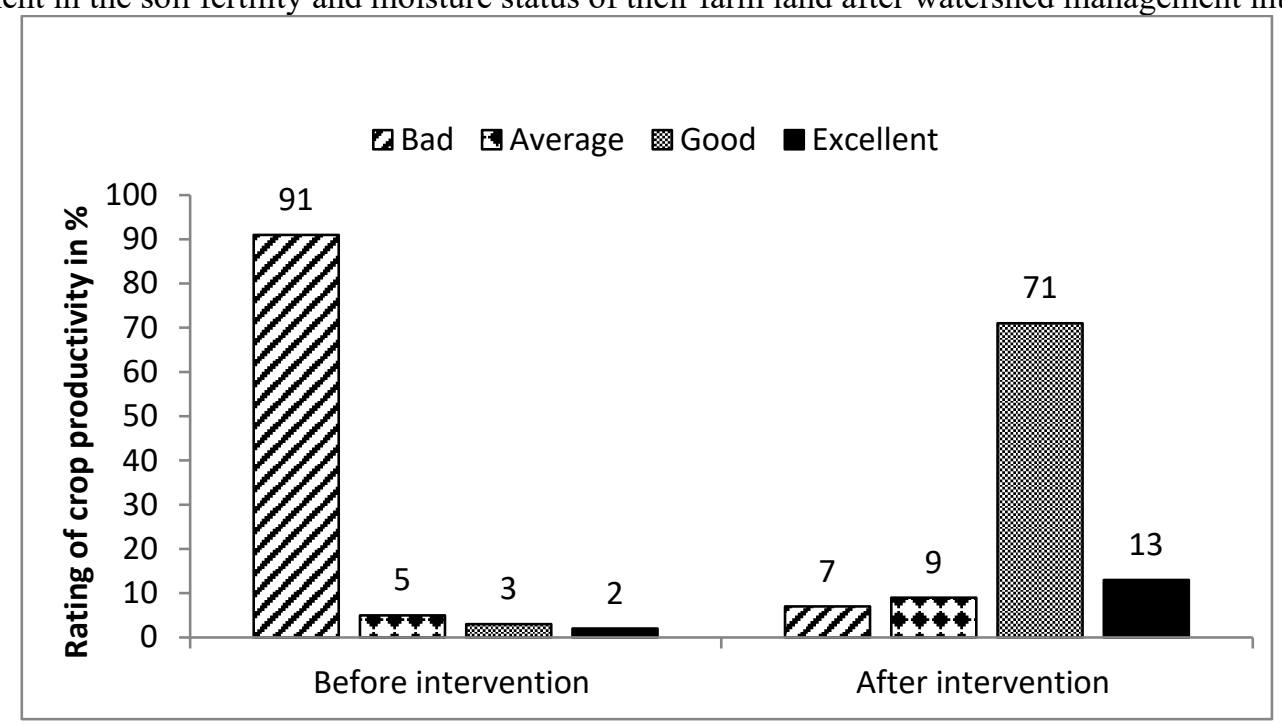

Figure 3 : Rating of the respondents on crop productivity Source: House hold survey (2016)

\section{Estimation of some cereal crop productivity}

To assess the opinion of the households about the impact of the watershed management on productivity of commonly produced crops were selected to estimate with and without the project. Accordingly, crop production in the area includes the production of staple food crops and cereal crops. The land holding size of the surveyed house was found being 0.639 hectare with minimum and maximum of 0.62 and 2 hectares respectively. In other word, about half of the respondents were smallholder farmers who have less than one hectare. Therefore, for the purpose of estimating the productivity of some cereal crop before and after the watershed management intervention, their land holding size was taken as one hectare. Then, based on the estimation of each respondent, the crop productivity is calculated per hectare per year as follow: 
Table3: Crop productivity in $\mathrm{Kg} / \mathrm{ha} / \mathrm{y}$

\begin{tabular}{lccc}
\hline Crop type & Before intervention & After intervention & \% of change after \\
\hline Wheat & 1250 & 2600 & 108 \\
Barely & 800 & 2400 & 200 \\
Peas & 650 & 1450 & 123 \\
Beans & 750 & 1600 & 113 \\
Teff & 750 & 1500 & 100 \\
Maize & 1250 & 2500 & 100 \\
Yam & 2100 & 20,000 & 852.4 \\
potato & 3500 & 20,000 & 471.4 \\
\hline
\end{tabular}

Source: Household Survey (2016)

The calculated average production difference presented in Table 3 showed that higher amount of all cereal crop production is observed in after intervention of the watershed management project. The average estimation in the table revealed that the production of Yam has increased by eight folds, potato by four folds, barley by two folds and rest crop (wheat, maize, teff, peas and beans) increased by double respectively. This means the crop productivity after intervention was higher than when compared the productivity each crop before the project.

The household survey result shows that the annual production of cereal crops has been increasing in the study area after the intervention of watershed management. Moreover, the focused group discussion, in-depth interview and key informants' information noticed the tendency of increment in production of all cereal crops in the study site. This finding is in line with the findings of Tesfaye Habtamu (2010). The study has found out that watershed management project in Lenche Dima,Tsegur Eyesus and Dijjil watershed in the Northern part of the country has contributed through maximizing the amount of food production.

According to Gebregziabher et al. (2016), study on the impact community based watershed management in Northern Ethiopia indicated that the crop productivity increased three to four folds. The reasons for such significant improvements were due to enhancement of soil fertility and soil water as result of land management measures implemented. Another study conducted in India by Mondal et al .(2012) analyzed that the cumulative effect of land based intervention was reflected through favorable change in bio-physical indicators which ultimately led to increased productivity almost all crops grown.

\section{Conclusions and Recommendations \\ Conclusions}

The impact of watershed management on crop productivity in the case of Mount Damota watershed was evaluated by assessing opinions of farmers. During the study focus was given to the community based campaign to watershed based soil and water conservation, perception, rating and estimation of respondents on crop productivity after watershed management. Accordingly, the watershed management is under gone by mobilizing the local community and organizing in different development teams. This in turn contributed to the achieved of the watershed management field works by gaining free labor from the community. Moreover, involving the local people has boosted the cooperation and sharing experiences between the local people, development agents and local government.

The finding on perception, rating and estimation on the impact of watershed management on crop productivity revealed that improvement has been observed by the local people on the production of different crops after the inception of the project. As majority of the respondents indicated the crop productivity increment is due to the improvement in the soil fertility and moisture status of their farm land. The improvement in crop productivity is better their family situation particularly in satisfying their needs. However, the different soil and water conservation structure in the plot of land is competing to the proportion of their crop production. Furthermore, the time period which is required to observe improvement from each soil and water conservation structures is the main challenges encountering.

\section{Recommendations}

Based on the findings of the study the following are forwarded;

* Watershed management to be effective on the ground involvement of the local people at grass root level should be given priority emphasis.

* Awareness and capacity building training should be given to the local people on how to manage and maintain natural resources.

* Compensating the local people particularly those their farm land proportion to crop production is significantly reduced by the installation of different structures.

* Disseminating improved farms technologies like improved seeds to enhance and support the productivity of smallholder farmers.

* Further empirical studies to be conducted to analyze and dig out the bio-physical and socio-economic 
impacts of watershed management at various scales.

\section{Acknowledgement}

I would like to extend my special thanks to Matusala Mada without whom the field data collection processes would have been impossible and the cooperative sense of the farm households of Damota watershed I would like to express my deeper gratitude to them.

\section{References}

Alemayehu, A. (2007). Impact of terrace development and management on soil properties in Anjeni area, West Gojam. MSC thesis, Addis Ababa University, Ethiopia. p. 72.

Alemneh, D. (2003). Intergrated Natural Resource Management to Enhance Food Security: The Case for Community Based Approaches in Ethiopia. Rome: FAO.

Binyam, A. and Desale, K. (2014). The Implication of Integrated Watershed Management for Rehabilitation of Degraded Lands: Case Study of Ethiopia highlaands. Journal of Agriculture and Biodiversity Research.ISSN 2277-0836; Volume 3, Issue 6, pp. 78-90.

Bledsoe,L.k.andGraham,A.J.(2005).TheUseofMultipleEvaluationApproachesin Program Evaluation.American Journal of Evaluation, 26, 302-319.

Davenport,E.T. (2003). The Watershed Project Management Guide. ISBN 1-58716-092-7. A CRC Press CompanyBoca Raton London New York Washington, D.C.

Evans, A. E. V.; Giordano, M.; Clayton, T. (Eds.) (2012). Investing in agricultural water management to benefit smallholder farmers in Ethiopia.AgWater Solutions Project country synthesis report. Colombo, Sri Lanka: International Water Management Institute (IWMI). 35p.(IWMI Working Paper 152). doi: 10.5337/2012.215.

Esser, K., Vagen, T., Talahun, Y. and Mitiu, H. (2002). Soil conservation in Tigray, Ethiopia. Noragric Report No. 5 February 2002.

EPA .(2012). National Report of Ethiopia, the United Nations Conference on Sustainable Development (Rio+20). Federal Democratic Republic of Ethiopia, Addis Ababa.

ESCAP. (2001). South Asia Sub-Regional Report for the world Summit on Sustainable Development. Task Force for the Preparation of WSSD in Asia and the Pacific World Summit on Sustainable Development (WSSD)

Gaddis, B., Erica, J. and Voinov, A. (2008). Lessons for successful participatory watershed modeling: A perspective from modeling practitioners. Ecological modeling, 197-207.

Gay, R.L., Mills, E.G., Airasian, P. (2009).Educational Research:Competencies for AnalysisandApplications.Florida,USA:Merrill,Pearson,Upper SaddleRiver, New JerseyColumbus, Ohio.

Heathcote, W.S. (2009). Integrated Watershed Management Principles and Practices. Second edition school of Engineering University of Guelph.

Hurni,H.(1986).GuidelinesforDevelopmentAgentsonSoilConservationinEthiopia.Switzerland:Community ForestandSoilConservationDevelopmentDepartment, Ministryof Agriculture,Ethiopia.

Gebregziabher, G.; Abera, D. A.; Gebresamuel, G.; Giordano, M.; Langan, S. (2016). An assessment of Integrated watershed management in Ethiopia. Colombo, Sri Lanka: International Water Management Institute (IWMI). 28p. (IWMI Working Paper 170). doi: 10.5337/2016.214

Gebreyesus, B. and Kirubel, M. (2009). Estimating Soil Loss Using Universal Soil Loss Equation (USLE) for Soil Conservation planning at Medego Watershed, Northern Ethiopia Center for Development Research (ZEF), University of Bonn, Walter-Flex-Str. 3,D-53113 Bonn, Germany. Mars land Press Journal of American Science 5(1), 58-69.

Kameri-Mbote, p. (2007). Water, Conflict, and Cooperation: Lessons from the Nile River Basin. Woodrow International Center Scholars.

Kebede, W.; Awdenegest, M. and Fantaw, Y.(2013). Farmers' perception of the effects of soil and water conservation structures on crop production: The case of Bokole watershed, Southern Ethiopia. African Journal of Water Conservation and Sustainability Vol. 1 (5), pp. 071-080.

Kebede, W. (2015). Evaluating watershed management activities ofcampaign work in Southern nations, nationalities and peoples' regional state of Ethiopia. Wolancho Environmental Systems Research (2015) 4:6 DOI 10.1186/s40068-015-0029-y.

Kidanemaraim , J. (2009). Participatory Integrated Water Resources Management (IWRM) Planning: Lessons from Berki Catchment, Ethiopia.

Kumbhar, V. Kulkarni, S., Kumbhar, S. and Arun, V. (2012). Participatory Watershed Management in South Asia: A Comparative Evaluation with Special References to India. International Journal of Scientific \& Engineering Research, Volume 3, Issue 3, March-2012 1, 1-9.

Lakew,D.,Curucci,V.,Asrat,W.,Yitayew,A.(Eds). (2005).Community Based Participatory Watershed Development. Addis Ababa, Ethiopia: Ministry of Agriculture and Rural Development.

Lal, R. (2000). Integrated Watershed Management in the Global Ecosystem. CRC press, London 
Loucks, D.P. (2000). Sustainable Water Resource Management. Water International , 3-10.

Meakin, S., (1992). The Rio Earth Summit: Summary of the United Nations Conference on Environment and Development.

Meshesha, B. Y. and Birhanu, B. S. (2015). Assessment of the Effectiveness of Watershed Management Intervention in Chena Woreda, Kaffa Zone, Southwestern Ethiopia. Journal of Water Resource and Protection, 2015, 7, 1257-1269.

Mintesinot, A. (2007). Watershed Management: Effects and Problems, The Case of Meret Project in KebelieChekorti Sub-Catchement,Kalu Woreda, Amhara Regional State. Addis Ababa: Addis Ababa University.

Mondal, B., Singh, A. and Sekar, I. (2012). Impact of Watershed Development Programmes on Crop Productivity: A Decomposition Analysis. Indian Research Journal of Extension Education, Special Issue (Volume II)

Pound, B. and Jonfa E. (2005). Soil Fertility Practices in Wolaita Zone, Southern Ethiopia: Learning from Farmers.

Salerto, I. (2006) Impact Assessment of the Soil and Water Conservation Project: Participatory Impact Assessment. M.Sc. Thesis, University of Jyvaskyla, 2006.

Sheng, C.T. (ed). (2001). Important and Controversial Watershed Management Issues in Developing Countries. Sustaining the Global Farm. Selected Papers from the $10^{\text {th }}$ International Soil Conservation Organization Meeting held May 24-29, 1999 at Purdue University, USDA-ARS National Soil Erosion Research laboratory.

Seaba, N. (2006). Public Participation: Rhetoric or Reality? An Analysis of Planning and Management. In the Nanda Devi Biosphere Reserve. Msc. Thesis. University of Manitoba, Winnipeg, Canada.

Sengupta, M. and Dalwani, R. (Edi.). (2008). Evaluation of socio-economic and environmental impacts of the watershed management projects: A case study of theZanjan river restoration project. Proceedings of Taal2007: the 12 World Lake conference: 1214-1219.

Sreedevi, T.K., Joshi, P.K., Jha, A.K. and Wani, S.P. ( 2009). Scaling-out Community Watershed Management for Multiple Benefits in Rain fed Areas.National Centre for Agricultural Economics and Policy Research, New Delhi 110 012, India; 2International Crops Research Institute for the Semi-Arid Tropics (ICRISAT), Patancheru 502 324, Andhra Pradesh, India.

Singh, P., Behera, H.C and Singh, A.(2010). Impact and Effectiveness of" Watershed Development Programmes "in India Review and Analysis Based on the Studies

Conducted by Various Government Agencies and Other Organizations. India: Centre for Rural Studies, National Institute of Administrative Research, Lal Bahadur Shastri National Academy of Administration Mussoorie248179.

Prokopy,LandGenskow,K.(2013).UsingSocialIndicatorsinWatershedManagementProjects.USA: Watershed Academy.

Ridolfi,J.K.,Vorster,PandMicheli,L.(2010).IndicatorsandPerformanceMeasuresforNorth BayWatersheds. Sierra: NorthBayWatershedAssociation.

Tesfaye, H. (2011). Assessment of Sustainable Watershed Management Approach: A Case Study in Leche-Dima, Tsegur Eyesus and Dijjil Watershed. Cornell University.

Temesgen, G.( 2015). The implications of watershed management for reversing land degradation in Ethiopia. Research Journal of Agriculture and Environmental Management. Vol. 4(1), pp. 005-012, January, 2015. Available online at http://www.apexjournal.org ISSN 2315 - 8719@ 2015 Apex Journal International.

Tripathi, Y.C, Pandey, B.K and Kaushik, P.K. (2007). Participatory Approach to Watershed Management in India. Rain Forest Research Institute, Deovan, Jorhat (Assam).

$\mathrm{Xu}, \mathrm{D}$., Jia, S. and Zhou, D. ( 2011).The temporal and spatial variability of soil properties in an agricultural system as. Journal of Food, Agriculture \& Environment Vol.9 (3\&4) 669 - 676.

Yachan, A. Spaliviero, M., De Dapper, M and Mannaerts, C. (2011). Participatory Approach for Integrated Basin Planning with Focus on Disaster Risk Reduction: The Case of the Limpopo River. Water 2011, 3, 737-763; doi: $10.3390 / \mathrm{w} 3030737$

Yoganand, B. and Gebremedhin, T. ( 2006). Participatory Watershed Management for Sustainable Rural Livelihoods in India. Selected working paper prepared for presentation at the Southern Agricultural Economics Association Annual Meetings Orlando, Florida.

Weber, S. and McKenney L. (2008).Watershed Management. Integrating People, Land and Water. Irvine, USA. RBF Consulting

Wondeamlak, B. (2003). Towards integrated watershed management in highland Ethiopia: the chemoga watershed case study.

WB. (2006).Integrated Water Resources Management (IWRM) Introduction to Principles.

WZARDD. (2015). Wolaita Zone Agriculture and Rural Development Department Annual Reports, Sodo, Ethiopia: Unpublished. 